\title{
Молекулярный скрининг образцов селекционно-генетических коллекций ВНИИКХ
}

\author{
В.А. Бирюкова*, И.В. Шмыгля, А.В. Митюшкин, А.А. Мелёшин, В.А. Жарова \\ Всероссийский НИИ картофельного хозяйства имени А.Г. Лорха, Красково, \\ Московская область, Россия \\ *e-mail:vika_biruykova@inbox.ru
}

В результате многолетней работы во ВНИИКХ сформирована генетическая коллекция биоресурсов картофеля, представленная родительскими линиями и донорами (сортообразцами и гибридами), полученными на основе беккроссов межвидового происхождения. В настоящее время коллекция насчитывает более 600 генотипов картофеля, обладающих уникальным набором ценных признаков для основных направлений селекции: полевой устойчивости к фитофторозу, экстремальной устойчивости к $\mathrm{X}$ и $\mathrm{Y}$ вирусам картофеля, комплексной устойчивости к обоим видам картофельной цистообразующей нематоды, повышенной крахмалистости и пригодности к переработке по показателям цвета чипсов.

Образцы коллекции, полученные методами накапливающих и синтетических скрещиваний, вновь вовлекаются в гибридизацию с целью повышения уровня полигенных признаков и расширения их генетического разнообразия, используются в практической селекции, в том числе различными НИУ, сотрудничающими с ВНИИКХ по созданию новых сортов картофеля для разных почвенноклиматических условий РФ. С помощью методов маркер-вспомогательной селекции проведен скрининг образцов генетической коллекции ВНИИКХ на наличие генов устойчивости к картофельной цистообразующей нематоде, $\mathrm{X}$ и $\mathrm{Y}$ вирусам картофеля. В результате выделены гибриды картофеля с комбинацией молекулярных маркеров - 4421-16 (Poko× Русский сувенир) (H1, Grol-4, Ry $y_{\text {sto }}$ ), 4707-32 (Alwara × 88.17/72) (Gro1-4, Gpa2, Ry sto, Rx1), 4701-14 (Alwara $\times$ Русский сувенир) (Gro 1-4, Gpa2, Ry sto $R x 1), 4701-16$ (Alwara $\times$ Русский сувенир) (Gpa2, $R y_{\text {sto }}$, $R x 1), 2646-11$ (92.13-186×91.30-66) (Grol-4, Gpa2, $\left.R y_{a d g}, R x 1\right), 2657-5$ (Эффект $\times$ 2372-66) (Gpa2, Ry adg,$R x 1), 92.13-163\left(\right.$ Pecypc $\times 655$ m-30) $\left(H 1, R y_{s t o}, R y_{a d g}\right), 1683-1$ (Метеор × Фиолетовый) (H1, Gpa2, Ry sto Rxl), 1327-1 (Лира × Raja) (H1, Grol-4, Gpa2, Rxl), 4434-1 (Roko× Аврора) (H1, Grol-4, Ry sto $), 4525-4$ (Вектор × Аврора) $\left(H 1, G p a 2, R y_{a d g}, R x 1\right)$, представляющие интерес для дальнейшей селекции. Данные молекулярного скринирования о наличии генов устойчивости к патогенам служат ценной информацией для селекционеров как один из важных критериев при составлении программ по гибридизации картофеля.

Благодарности: Работа выполнена в соответствии с НИОКТР, номер госрегистрации 0596-2018-0003. 